\title{
Technique Description for Manipulative Therapy
}

\author{
Harihara Prakash $\mathrm{R}^{*}$ \\ Principal \& Head, KM Patel Institute of Physiotherapy, India
}

Submission: August 10, 2017; Published: August 21, 2017

*Corresponding author: R Harihara Prakash, Principal \& Head, KM Patel Institute of Physiotherapy, India, Email: saihari76@gmail.com

\section{Introduction}

Manipulations of the spine are always fascinating to both the therapist and the patient as it provides instantaneous results. The 'click' sound that is heard while manipulating gives a sense of achievement to both of them. In this article, I shall be providing you tips for successful manipulation of the spinal column.

The methods used for explaining the spinal manipulation presented here are as follows:
A. Position of Patient
B. Position of Physiotherapist
C. Point of contact
D. Segmental point of contact
E. Re-enforcement
F. Line of drive

Each of this system is necessary to the development of a thorough understanding of each method of manipulation.

\section{Position of the patient}

Patient position refers to the position which the patient assumes on the treatment table. The various options include having the patient in side lying, prone, supine or seated. Describing the side lying patients will also list -show the side on which the patient should lie. This is done by indicating either PROBLEM SIDE UP or DOWN. The PROBLEM SIDE means the side of the spine to be treated either left or right. Positioning the patient can also be changed to include certain positions of the manipulative table. The head piece can be deflected 15-20 degrees downwards or upwards.

\section{Position of the physiotherapist}

The Physiotherapist stance refers to the position which he assumes relative to the Manipulation table. It includes being in the following positions

a. anterior to the patient, at the side of the table toward which the patient is facing b. Inferior, at the side of the table, facing toward the head of the table

c. Lateral, standing on the lateral side of the head of the table

d. At the head of the table, standing at the head of the table, facing toward the foot of the table

e. At the table slightly toward a specific side

f. Position of the Physiotherapist feet is an important part of delivering a good manipulation

g. The Physiotherapist feet must be placed in a position which allows and fosters good balance throughout the entire manipulating method

h. When he stands either an anterior or inferior stance, he faces the side of the table and pivots both feet about 40-45 toward the head of the table.

\section{Point of contact}

This refers to that position of the Physiotherapist's manipulating hand/s through which the manipulating thrust is applied. Note that the thrust is usually applied through one hand, sometimes in certain cases, techniques will require that the manipulative thrust be applied with both the hands.

Specific contact points on the Physiotherapists hand which are used include the following bony areas:

a. Thumb-thenar eminence

b. Thumb-MCP joint

c. Thumb-distal aspect of the tip

d. Index finger-PIP joint

e. Index finger-finger tip

f. Third finger-finger tip

g. Third finger-Proximal or middle phalanx 
h. Fifth finger-MCP joint

i. Hypothenar eminence

j. Pisiform bone

Locating the correct contact point, the Physiotherapist must also ensure that the alignment of the fingers is appropriate for a correct vector of force for the appropriate line of drive.

\section{Segmental point of contact}

This is the part of the patient, where the thrust is applied.

The segmental contact points in each region of the spine include the following:

a. Ischial tuberosity

b. Posterior Superior Iliac Spine

c. Mammillary Process (Lumber Spine)

d. Transverse Process (1st Cervical vertebra and thoracic region)

e. Spinous Process (Cervical, Thoracic and Lumbar regions)

f. Articular Pillar (Cervical region)

\section{Re-enforcement}

Refers to the second contact point on the patient's body, which the Physiotherapist uses to ensure that the patient remains in a stable position during the manipulative procedure. Do not thrust through the stabilization hand. Keep manipulations tight and focused short lever.

\section{Line of drive}

This is the term used to describe the direction of the vector of force which the physiotherapist delivers to the effect of manipulation. Lines of drive can include:

Posterior to Anterior

a. Anterior to Posterior

b. Medial to Lateral

c. Lateral to Medial

d. Inferior to Superior

e. Superior to Inferior

f. Through the plane line of disc

g. Through the plane line of articulation

\section{Torque}

Torque is used in this manual to describe a screw-like motion of the manipulating hand, which is utilized in some manipulation to correct lateral wedging of a vertebra or disc distortion. Direction of torque is described as either clockwise or counter clockwise. The torque of a manipulation is designed to close an open wedge of a disc. These tips help the physiotherapist to undertake the task of manipulation with successful outcome. In the next edition, I shall be writing about when to manipulate the spine and what is the physiology behind the act of manipulation.

\section{Your next submission with Juniper Publishers will reach you the below assets}

- Quality Editorial service

- Swift Peer Review

- Reprints availability

- E-prints Service

- Manuscript Podcast for convenient understanding

- Global attainment for your research

- Manuscript accessibility in different formats ( Pdf, E-pub, Full Text, Audio)

- Unceasing customer service

Track the below URL for one-step submission https://juniperpublishers.com/online-submission.php 